\title{
Perencanaan Strategis Sistem Dan Teknologi Informasi Pada Bank Sampah Kota: Studi Kasus Bank Sampah Kota Prabumulih
}

\author{
Eka Sri Wahyuni \\ Universitas Bina Darma \\ Email: eka.sriwahyuni92@gmail.com
}

\begin{abstract}
Waste today is the most influential factor on the environment, it can not be denied that the waste will always exist as long as the activity of life is still running. Law no. 18 Year 2008 on trash management explains about the need to change the pattern of conventional trash management into trash management which is based on trash reduction and handling. The role of Bank Trash becomes important as one of the organizations that is expected to be able to carry out the task to be able to provide an active solution to the trash problem in Prabumulih City. This study aims to analyze the condition of information systems and information technology (IS / TI), in the Trash Bank environtment. Trash Bank Prabumulih City was chosen as the object of research because the existence of garbage bank becomes a very important requirement at this time. The literature review is used as a method in reviewing journals to determine the role of information systems and information technology (IS / IT) in optimizing interactions between organizations, customers and the wider community. This research produces information about the condition of information system and information technology (IS / IT) in Prabumulih Trash Bank so it can help give solution in an effort to increase the role of Information System and Information Technology in supporting the operational activity of Prabumulih Trash Bank.
\end{abstract}

Keywords: Trash bank, Ward-Peppard Methodology, and Strategic planning IS/IT

\section{Pendahuluan}

Limbah sampah merupakan Salah satu permasalahan besar yang dialami kota-kota di indonesia. Sampah dapat diartikan sebagai konsekuensi dari adanya aktivitas kehidupan manusia, karena sampah akan selalu ada selama aktivitas kehidupan masih terus berjalan. Volume sampah dapat dipastikan akan selalu meningkat seiring denga pola konsumerisme masyarakat yanng semakin meningkat. Undang-undang no. 18 tahun 2008 tentang pengelolaan sampah menjelaskan tentang perlunya perubahan pola pengelolaan sampah konvensional menjadi pengelolaan sampah yang bertumpu pada pengurangan dan penanganan sampah. Pengurangan dapat dilakukan dengan kegiatan pembatasan timbulan sampah, mendaur ulang dan memanfaatkan kembali sampah yang biasa dikenal dengan sebutan 3R (reduce, reuse, recycle).

Undang-undang no. 18 tahun 2008 serta Peraturan Pemerintah No. 81 Tahun 2012 mengamanatkan perlunya perubahan paradigma yang mendasar dalam pengelolaan sampah yaitu dari paradigma kumpul-angkut-buang, menjadi pengolahan yang bertumpu pengurangan dan penanganan sampah. Paradigma pengelolaan sampah yang bertumpu pada pendekatan akhir sudah saatnya ditinggalkan dan diganti dengan paradigma yang menganggap sampah sebagai sumber daya yang mempunyai nilai ekonomis dan dapat dimanfaatkan.

Bank Sampah Prabumulih (BSP) adalah salah satu organisasi yang diharapkan akan mampu mengemban tugas untuk dapat memberikan solusi aktif terhadap permasalahan sampah di Kota Prabumulih. Dalam upaya pengembangan dan pencapaian visi dan misinya yang berbasis pelestarian lingkungan hidup, Bank Sampah Prabumulih turut serta menjadi mitra Pemerintah dalam usaha-usaha dibidang lingkungan hidup, seperti melakukan kegiatan

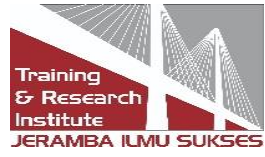


yang bersifat social engineering yang memberikan pelatihan-pelatihan kepada masyarakat, seperti pelatihan hidroponik untuk Mengenalkan dan mensosialisasikan bagaimana cara berkebun secara pintar dengan metode hidroponik, juga sekaligus memberdayakan masyarakat dalam bidang ekonomi sosial yang berbasis pelestarian lingkungan hidup dengan cara menumbuhkan kesadaran masyarakat terhadap lingkungan, serta mengajarkan kepada mereka bagaimana cara memisahkan dan mengolah sampah secara bijak. Berdirinya Bank Sampah ini dapat menjadi momentum awal dalam membina kesadaran kolektif masyarakat untuk mulai memilah, mendaur ulang dan memanfaatkan sampah hingga memiliki nilai jual. Harapannya untuk dapat mengurangi jumlah timbunan sampah yang diangkut ke TPA dan mendorong pemberdayaan ekonomi masyarakat.

Bank Sampah Prabumulih saat ini belum memiliki perencanaan strategis yang baik dalam menjalankan kegiatan pengelolaan sampah, sehingga ingin melakukan suatu terobosan yang diharapkan akan mampu memberi solusi untuk dapat mengurangi permasalahan sampah sehingga mampu mewujudkan visi dan misi organisasi dalam mengembangkan dan melestarikan lingkungan hidup. Berkenaan dengan permasalahan sampah yang semakin banyak, maka Bank Sampah Prabumulih berupaya memberikan suatu inovasi untuk membuat sampah yang mulanya kotor menjadi bermanfaat sehingga dapat menambah (income) pendapatan masyarakat. Sampah-sampah tersebut dapat diolah kembali agar sampah-sampah tersebut mempunyai nilai ekonomis dan dapat diolah dengan bijak serta dimanfaatkan kembali sehingga memiliki nilai jual, misalnya untuk energi, pupuk kompos, bahan baku industri dan lain-lain. Pemanfaatan daur ulang sampah ini, dapat menjadi keunggulan dari perencanaan strategis sistem informasi dan teknologi informasi bagi BSP.

Masalah yang ditemui adalah Bagaimana membuat perencanaan strategis sistem dan teknologi informasi pada Bank Sampah Prabumulih sehingga mampu meningkatkan kesadaran masyarakat untuk dapat memperoleh (income) dari hasil pengolahan sampah yang berbasis pelestarian lingkungan hidup, sesuai dengan visi dan misi organisasi.

Perencanaan strategis SI/TI akan dibatasi pada penelitian yang menganalisis kondisi sistem informasi dan teknologi informasi (SI/TI) yang ada di Bank Sampah Prabumulih. Frame work yang digunakan dalam membuat perencanaan strategis SI/TI ini adalah Frame work Ward and Peppard. Analisis lingkungan internal Bank Sampah menggunakan metode SWOT dan PEST digunakan untuk analisis lingkungan eksternal. Data-data analisis didapat dari hasil wawancara dengan Direktur Bank Sampah Prabumulih dan staf administrasi/Teller selaku user yang terlibat langsung dalam pengoperasian SI/TI, mempelajari rencana pegembangan Bank Sampah serta melakukan observasi dan pengamatan langsung terhadap aplikasi sistem informasi dan teknologi informasi di Bank Sampah Prabumulih.

\section{Tinjauan Literatur}

\subsection{Pengertian Perencanaan}

Perencanaan adalah suatu fungsi manajemen yang paling penting, karena berbagai fungsi manajemen lainnya baru berperan apabila perencanaan selesai dilaksanakan dan harus berpedoman pada perencanaan yang telah ditetapkan. Disamping itu, perencanaan merupakan jembatan terpenting antara saat ini dan waktu yang akan datang dan diharapkan dapat meningkatkan pencapaian dari suatu hasil. Fungsi perencanaan mencakup kegiatan manajerial yang menentukan sasaran dan alat yang tepat untuk mencapai sasaran tersebut. Perencanaan juga menjadi salah satu indikator manajemen yang baik. (David, 2009). Menurut Handoko (2003) perencanaan adalah pemilihan sekumpulan kegiatan dan pemusatan selanjutnya apa, kapan, bagaimana, dan oleh siapa sekumpulan kegiatan tersebut harus dilakukan. Perencanaan

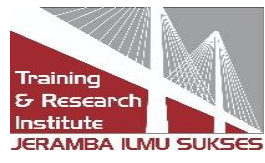


adalah proses di mana manajer secara matang dan bijaksana memikirkan dan menetapkan sasaran serta tindakan berdasarkan beberapa metode yang diperlukan untuk mencapainya, dan proses itu sendiri merupakan suatu cara sistematik yang ditetapkan untuk malakukan kegiatan.

Dari kedua definisi perencanaan tersebut dapat dipahami bahwa sesungguhnya perencanaan adalah proses pengambilan keputusan pada masa sekarang untuk mengantisipasi dampakdampak yang diperkirakan muncul di masa mendatang. Landasan dari setiap perencanaan adalah kemampuan manusia untuk sadar memilih alternatif masa depan yang dikehendakinya dan kemudian mengarahkan daya upayanya untuk mewujudkan masa depan yang dipilih tersebut. Oleh sebab itu, supaya perencanaan tepat pada sasaran, maka perlu mempertimbangkan penggunaan strategi yang tepat.

\subsection{Pengertian Strategis}

Stephanie, seperti yang dikutip Umar (2001:31) dari Sukristono, mendefinisikan strategi sebagai suatu proses penentuan rencana para pemimpin puncak yang berfokus pada tujuan jangka panjang organisasi, disertai penyusunan suatu cara atau upaya bagaimana agar tujuan tersebut dapat dicapai. Hal ini mewujudkan bahwa betapa perumusan strategi bukanlah pekerjaan mudah tetapi penuh dengan tantangan. Karena perumusan strategi selalu dipengaruhi oleh berbagai hal seperti : (1) penilaian yang bersifat subyektif, (2) perhitunganperhitungan yang tidak selalu dapat dikualifikasikan, (3) kenyataan bahwa bisnis organisasi selalu bergerak dalam kondisi dinamis yang pada dirinya mengandung ketidakpastian, (4) adanya faktor-faktor yang berada di luar kemampuan organisasi untuk mengendalikannya. (Siagian,2007).

Setelah memahami pengertian perencanaan dan strategi diatas secara terpisah, maka sebagai sebuah konsep yang utuh, para pakar mendefinisikan perencanaan strategis secara berbedabeda. Perencanaan Strategis (Strategic Planning) adalah sebuah alat manajemen yang digunakan untuk mengelola kondisi saat ini untuk melakukan proyeksi kondisi pada masa depan, sehingga rencana strategis adalah sebuah petunjuk yang dapat digunakan organisasi dari kondisi saat ini untuk mereka bekerja menuju 5 sampai 10 tahun ke depan (Kerzner,2001). Untuk mencapai sebuah strategi yang telah ditetapkan oleh organisasi dalam rangka mempunyai keunggulan kompetitif, maka para pimpinan perusahaan, manajer operasi, haruslah bekerja dalam sebuah sistem yang ada pada proses perencanaan strategis / strategic planning (Brown,2005). Kemampuan manufaktur, harus dipergunakan secara tepat, sehingga dapat menjadi sebuah senjata yang unggul dalam sebuah perencanaan strategi (Skinner,1969). Untuk mencapai sebuah strategi yang telah ditetapkan oleh organisasi dalam rangka mempunyai keunggulan kompetitif, maka para pimpinan perusahaan, manajer operasi, haruslah bekerja dalam sebuah sistem yang ada pada proses perencanaan strategis (Brown,2005). Kemampuan manufaktur, harus dipergunakan secara tepat, sehingga dapat menjadi sebuah senjata yang unggul dalam sebuah perencanaan strategi (Skinner, 1969).

Sedangkan maksud dan tujuan penerapan perencanaan strategis suatu organisasi sangat bervariasi namun secara umum maksud dan tujuannya adalah.

1. Memperjelas tujuan dan sasaran

2. Menentukan arah dan prioritas

3. Mendorong cara pandang berbasis jangka panjang yang lebih luas

4. Mengenali hambatan-hambatan dan isu-isu kritis.

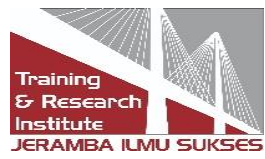


5. Menyediakan sebuah kerangka kebijakan dan pengambilan keputusan.

6. Memberitahukan pemanfaatan alokasi sumber daya (Corral, 2000).

\subsection{Proses Perencanaan strategis}

Tujuan dari proses perencanaan strategis adalah untuk memahami pentingnya dampak dari faktor eksternal serta membangkitkan semangat para pelaku utama dalam organisasi agar menghasilkan pelayanan bermutu, efektif dan efisien (Antoni, Akbar \& Fatoni, 2018; Antoni, Fikari, Akbar \& Jie, 2018; Akbar \& Antoni, 2019; Ariana, Azim \& Antoni, 2020; Antoni, Jie \& Abareshi, 2020). Sebagai sebuah proses, perencanaan strategis mencakup beberapa langkah atau tahapan yang masing-masing saling terkait. Wahyudi (1996) perencanaan strategis terdiri dari 3 (tiga) proses :

1. Pembuatan strategi (formulating) yaitu proses ini meliputi pengembangan misi dan tujuan jangka panjang, pengidentifikasian peluang dan ancaman dari luar serta kekuatan dan kelemahan organisasi, pengembangan alternatif-alternatif strategi dan penentuan strategi yang sesuai untuk digunakan.

2. Penerapan strategi (implementing) yaitu proses yang meliputi penentuan sasaran-sasaran operasional tahunan, kebijakan organisasi/perusahaan, memotivasi staf/karyawan dan

mengalokasikan sumber-sumber daya agar strategi yang telah ditetapkan dapat diimplementasikan.

3. Evaluasi (evaluating) yaitu proses yang mencakup usaha-usaha untuk mengawasi seluruh hasil dari pembuatan dan penerapan strategi, termasuk mengukur kinerja staf/karyawan dan organisasi/perusahaan serta mengambil langkah-langkah perbaikan jika diperlukan.

\section{Metode Penelitian}

\subsection{Desain Penelitian}

Penelitian ini merupakan penelitian studi kasus untuk mengangkat suatu permasalahan tentang perencanaan strategi berbasis sistem informasi dan teknologi informasi di Bank Sampah Prabumulih. Kerangka teoritik dalam penulisan ini menjelaskan tentang konsep strategi SI/TI, konsep perencanaan strategis SI/TI dan konsep metodologi perencanaan strategis SI/TI versi Ward and Peppard. Konsep-konsep tersebut berperan sebagai pemandu ilmiah dalam menentukan fokus penelitian dan dalam menganalisis data serta merumuskan hasil penelitian.

Penelitian yang dilaksanakan di Bank Sampah Prabumulih menggunakan pendekatan penelitian deskriptif kualitatif (Fauzi, Dencik \& Asiati, 2019). Dalam proses penelitian kualitatif peneliti melakukan pendekatan dan pengumpulan data dengan cara bertatap muka dan berinteraksi secara langsung dengan orang- orang di tempat penelitian. Penelitian kualitatif merupakan jenis penelitian yang temuan- temuannya tidak diperoleh melalui prosedur statistik atau bentuk hitungan lainnya. Pada penelitian kualitatif proses yang dilakukan adalah melakukan observasi dan mengumpulkan data-data terkait dengan objek yang akan diteliti, dan melakukan analisa untuk mencari data-data apa saja yang dapat diperbaiki dari sistem yang berjalan saat ini. instrumen pengumpulan data adalah dengan melakukan observasi secara langsung di lingkungan Bank Sampah Prabumulih yang berlokasi di J1. Arjuna Kelurahan Wonosari Kecamatan Prabumulih Utara Kota Prabumulih. Selanjutnya melakukan wawancara tatap muka terhadap Direktur Bank Sampah Prabumulih

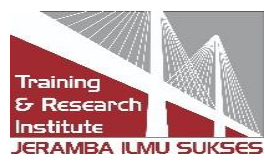


dan Teller di Bank Sampah Prabumulih. Informasi yang didapat dari wawancara tersebut berupa gambaran umum tentang Bank Sampah Prabumulih, jumlah Stakeholder dan proses transaksi, serta kondisi sistem informasi dan teknologi informasi yang ada pada Bank Sampah Prabumulih.

\subsection{Data Penelitian}

Data penelitian diperoleh dari stakeholder Bank Sampah Prabumulih, yang keseluruhannya berjumlah 13 orang terdiri dari,

1. Direktur (director)

2. Manajer humas (public relation manager)

3. Manajer keuangan dan akuntansi (finance and accounting manager)

4. Manajer bisnis dan manajemen (manager of business and management)

5. Manajer gudang dan distribusi (warehouse and distribution manager)

6. Manajer aset dan perawatan (asset managers and maintenance)

7. 2 orang staff Administrasi (Teller)

8. 5 orang Staff gudang

\subsection{Metode Analisis Data}

\section{Analisis SWOT}

Analisis SWOT merupakan salah satu metode analisis dalam manajemen strategis yang sudah terbukti sangat berguna untuk mengidentifikasi berbagai faktor secara sistematik untuk merumuskan strategi organisasi. Dasar pijak analisis ini terletak pada logika yang dapat memaksimalkan kekuatan (Strength) dan peluang (Opportunity) namun secara simultan dengan meminimalisir kelemahan (Weakness) dan ancaman (Threats).

Dengan analisis SWOT diharapkan dapat memberikan informasi gambaran kemampuan organisasi dan posisi kekuatan organisasi serta faktor kunci keberhasilan atau faktor-faktor strategis dalam mencapai visi dan misi organisasi. Informasi hasil analisis SWOT dapat dimanfaatkan sebagai umpan balik dalam penajaman rumusan misi dan dasar perumusan tujuan yang rasional serta acuan dalam menyusun strategi dan rencana kegiatan yang dilakukan.

$\begin{array}{cc}\text { S (Strenghts) } & \text { W (Weakness) } \\ \text { O } & \\ \text { unity) }\end{array}$




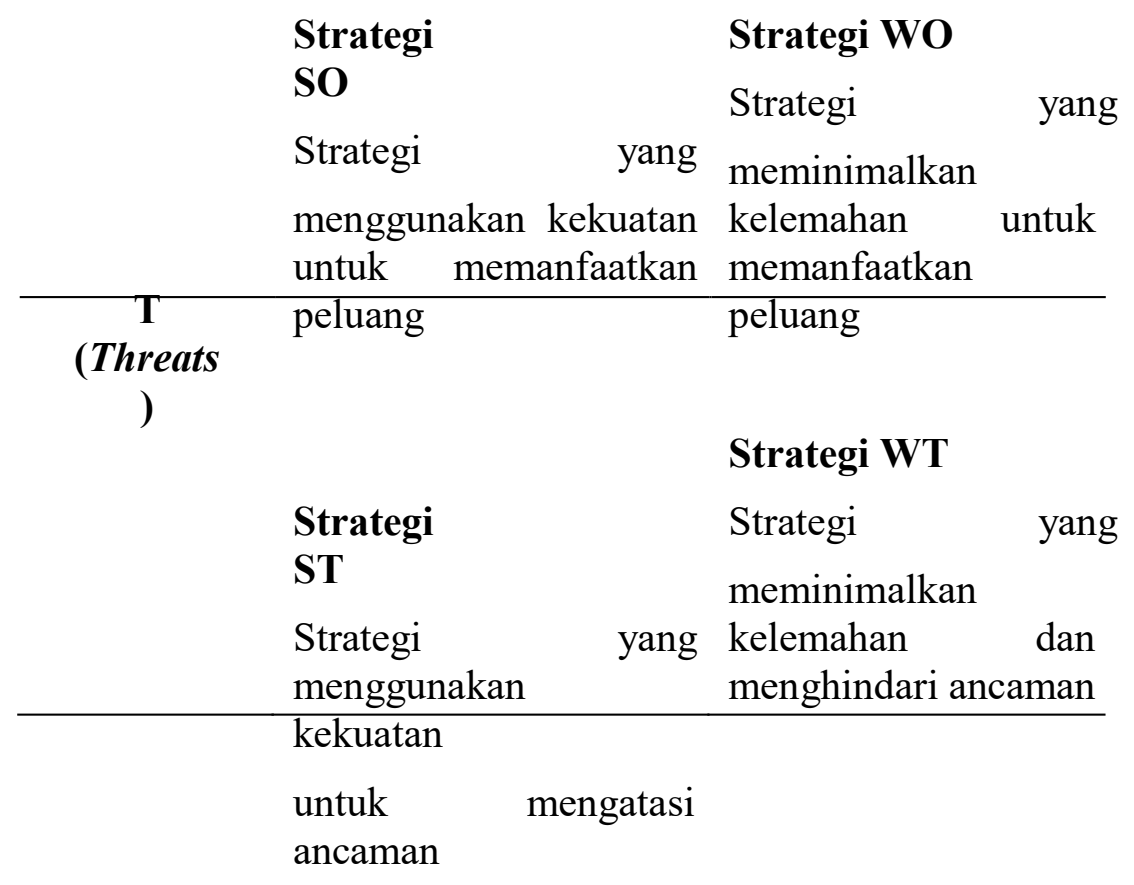


Gambar 1. Matriks SWOT [Rangkuti, 2006]

\section{Analisis PEST}

PEST digunakan untuk menggambarkan situasi dan kondisi lingkungan yang relevan dengan proses bisnis yang dilakukan suatu organisasi ditinjau dari 4 faktor yaitu faktor politik, ekonomi, sosial dan teknologi. Dengan mengenali keempat faktor tersebut secara baik dapat dimanfaatkan dalam menggali peluang bisnis yang ada atau ancaman yang mungkin menghambat proses bisnis sehingga langkah-langkah antisipasi dapat dilakukan dengan tepat dan cepat.

\section{Analisis McFarlan Strategic Grid}

McFarlan Strategic Grid digunakan sebagai alat bantu yang bermanfaat untuk memetakan aplikasi SI berdasarkan kontribusinya terhadap organisasi. Pemetaan dilakukan pada empat kuadran yaitu (strategic, highpotential, key operational and support). Dari hasil pemetaan tersebut didapat gambaran kontribusi sebuah aplikasi SI terhadap organisasi dan pengembangan dimasa mendatang (Ward and Griffith 1996).

a. Strategic yaitu aplikasi-aplikasi yang masuk dalam kategori ini adalah aplikasiaplikasi yang sangat penting untuk strategi dimasa depan.

b. Key Operational yaitu aplikasi-aplikasi kategori ini adalah aplikasi-aplikasi yang menjamin kesuksesan organisasi. Tanpa aplikasi-aplikasi akan sulit mencapai tujuantujuannya.

c. Support yaitu aplikasi-aplikasi yang tergolong kategoru Support adalah aplikasiaplikasi yang cukup membantu namun tidak menjadi syarat untuk kesuksesan organisasi.

d. High Potential yaitu aplikasi-aplikasi yang mungkin penting untuk kesuksesan organisasi dimasa depan tergolong dalam kategori ini.

\begin{tabular}{|l|l|}
\hline \multicolumn{1}{|c|}{ STRATEGIC } & HIGH POTENTIAL \\
\hline $\begin{array}{l}\text { - Applications that } \\
\text { are critical to } \\
\text { sustaining future } \\
\text { business strategy }\end{array}$ & $\begin{array}{l}\text { - Applications that } \\
\text { may be important } \\
\text { in achieving future } \\
\text { success }\end{array}$ \\
\hline $\begin{array}{l}\text { - Applications on which } \\
\text { the organization } \\
\text { currently depends } \\
\text { for success }\end{array}$ & $\begin{array}{l}\text { - Applications that } \\
\text { are valuable but } \\
\text { not critical to } \\
\text { success }\end{array}$ \\
\hline KEY OPERATIONAL & SUPPORT \\
\hline
\end{tabular}

Gambar 2. McFarlan Strategic Grid [Ward and Peppard, 2002]

\section{Hasil dan Pembahasan}

\subsection{Analisis Lingkungan SWOT}

Analisis lingkungan internal dan eksternal SI/TI Bank Sampah Prabumulih meliputi seluruh sumber daya sistem informasi dan teknologi informasi yang telah ada dan

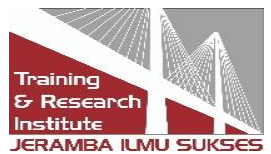


dimanfaatkan untuk keperluan bisnis. Adapun analisis SWOT Sekolah Tinggi Ilmu Teknik Prabumulih yang didapat pada hasil wawancara dan sebaran kuesioner dapat disimpulkan sebagai berikut :

a. Kekuatan (Strengths)

1. Keinginan kuat dari Bank Sampah Prabumulih untuk mengembangkan kegiatan operasional yang didukung SI/TI

2. BSP satu-satunya Bank Sampah yang berada di Kota Prabumulih dan mendapat

dukungan penuh dari pemerintah.

3. Pengalaman pendiri dalam mengelola Bank Sampah, belum ada pesaing dibidang

Organisasi yang sama di daerah Bank Sampah berdiri.

4. Tersedianya sarana dan prasarana untuk mendukung proses operasional seperti komputer,

5. SDM usia produktif yang melek teknologi.

b. Kelemahan (Weakness)

1. Sistem penerimaan sampah yang masih ditangani secara manual oleh organisasi Bank Sampah Prabumulih

2. Memiliki Aplikasi khusus Bank Sampah tetapi masih offline dan masih memiliki kekurangan pada pilihan jenis sampah, sehingga jika jenis sampah yang ditabung nasabah tidak tersedia pada aplikasi, dicatat secara manual dan terpisah pada Microsoft Excel.

3. Transaksi perhitungan hasil sampah yang dilakukan masih menggunakan Microsoft Exel.

4. Kurangnya sarana dan prasarana pendukung IT

5. Belum ada SDM yang khusus menangani IT

c. Peluang (Opportunities)

1. Perkembangan teknologi informasi sistem informasi dan komunikasi dan yang sangat cepat

2. Kemudahan akses internet, sehingga SDM dapat dengan mudah memanfaatkan teknologi untuk menyebarluaskan informasi melalui sosial media.

3. Dinas-dinas dan Instansi pemerintahan terkait yang terdaftar sebagai nasabah tetap,

karena dukungan penuh dari pemerintah.

d. Ancaman (Threats)

1. Pesaing lama yang memiliki usaha sejenis yang menyediakan pelayanan jasa angkut sampah kerumah-rumah, sehingga membuat masyarakat malas untuk menjadi anggota Bank Sampah.

2. Pesaing baru yang memiliki usaha sejenis dan SDM yang berkompeten dengan

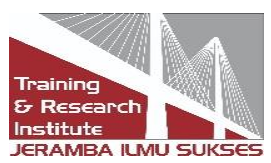


sarana prasarana penunjang yang lebih unggul.

\subsection{Analisis Lingkungan PEST}

Analisis lingkungan eksternal dilakukan dengan menggunakan pendekatan analisis PEST (Politics, Economics, Social and Technology). PEST digunakan untuk menggambarkan situasi dan kondisi lingkungan yang relevan dengan proses bisnis yang dilakukan suatu organisasi ditinjau dari

4 faktor politik, ekonomi, sosial dan teknologi.

a. Politik

Peran Bank Sampah menjadi penting dengan terbitnya Undang-undang No. 18 Tahun 2008 dan Peraturan Pemerintah No. 81 Tahun 2012 tentang pengelolaan sampah.

Strategi dalam faktor politik:

Undang-Undang dan Peraturan Pemerintah tersebut menjadi keunggulan tersendiri bagi keberlangsungan organisasi Bank Sampah dibanding kompetitor lain, sehingga dapat lebih menarik minat nasabah karena memberikan jaminan perlindungan yang kuat.

b. Ekonomi

Laju perkembangan ekonomi yang semakin pesat, dengan harga berbagai kebutuhan yang melambung tinggi, memicu masyarakat untuk lebih berhemat.

Strategi dalam faktor ekonomi:

Peluang untuk mengajak masyarakat mengumpulkan dan menabung sampah untuk dapat meningkatkan pendapatan semakin besar.

c. Sosial

Letak Bank Sampah yang strategis dan berada di kawasan Taman menjadi daya tarik tersendiri bagi BSP

Belum ada pesaing yang terlalu berarti bagi BSP. Bank Sampah Prabumulih telah menjadi satu-satunya 'Brand' Bank Sampah di Kota Prabumulih.

Strategi dalam faktor sosial:

1. Kemudahan dalam mensosialisasikan diri dan menarik minat masyarakat.

2. Brand yang baik menghasilkan kerjasama yang baik dengan perusahaan, atau lembaga apapun, karena sampah selalu ada dimana saja dan membutuhkan pengelolaan yang tepat.

d. Teknologi

Perkembangan Sistem Informasi dan Teknologi Informasi yang semakin pesat

Strategi dalam faktor teknologi:

1. Mengembangkan Sistem Informasi berbasi Teknologi Informasi

2. Meningkatkan jumlah sarana dan prasarana pendukung SI/TI

3. Merekrut SDM yang berkompeten dalam bidang pengelolaan SI/TI.

Rumusan Strategi Bank Sampah Prabumulih

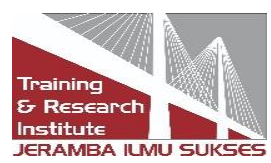


Rumusan strategi yang ada pada BSP, akan dilampirkan pada Tabel dibawah.

Tabel 1. Rumusan Strategi SWOT (SO-WO)

$\begin{array}{llll}\begin{array}{l}\text { pengembangan } \\ \text { mendukung }\end{array} & \text { SI/TI dalam } & \begin{array}{l}\text { meningkatkan kualitas } \\ \text { layanan }\end{array}\end{array}$

kegiatan operasional bank sampah.

Mensosialisasikan peran, tujuan dan manfaat adanya Bank Sampah bagi masyarakat melalui berbagai media baik online maupun offline.

Setiap instansi pemerintah wajib Rekruitmen SDM yang berkompeten dengan keahlian dibidang IT

Melakukan kerjasama dengan instansi terkait untuk Peningkatan efisiensi layanan internal dan terdaftar sebagai nasabah bank sampah Prabumulih, sebagai wujud kerjasama yang baik sebagai satu- satunya bank sampah milik Pemerintah Kota Prabumulih. eksternal.

Standarisasi baik dari segi hardware, software, sistem aplikasi untuk memudahkan pemeliharaan sarana.

Pendiri yang berpengalaman dibidangnya menjadi salah satu kekuatan bank sampah untuk dapat meningkatkan kualitas.

Belum adanya pesaing yang terlalu berarti memberi kemudahan bagi bank sampah untuk menciptakan brand.

Menambah sarana dan prasarana pendukung TI. Memanfaatkan SDM produktif untuk turut

berperan aktif melakukan promosi pada berbagai media sosial.

Membuat sebuah sistem informasi khusus yang akan membantu dalam proses operasional bank sampah yang dapat diakses secara online. 
Tabel 2. Rumusan Strategi SWOT (ST-WT)

$\overline{\text { ST }}$ WT

Mengajukan dan meangalokasikan Meninjau ulang fungsi SI/TI pada anggaran dana untuk penambahan perusahaan secara berkala bantuan motor dan mobil sampah sehingga benar benar sesuai target. kepada instansi terkait untuk dapat meningkatkan pelayanan, terutama pelayanan jasa angkut sampah Membangun sistem informasi bank kerumah-rumah. sampah berbasis website dan mobile banking untuk memberi kemudahan bagi nasabah

Meningkatkan kualitas sarana dan prasarana dengan membangun teknologi informasi yang terintegrasi untuk meningkatkan kualitas layanan

Membangun database terpusat Peningkatan kualitas SDM dengan melaksanakan pelatihan untuk penggunaan

Menjalin kerjasama dengan aplikasi yang akan diterapkan. instansi pemerintah maupun instansi lain dalam melakukan penggalian SDM potensial.

Peningkatan sarana dan prasarana baik perangkat keras maupun perangkat lunak pendukung IT.

Peningkatan kualitas

SDM 


\subsection{Analisis Strategi SI/TI}

Strategi SI/TI yang perlu dilakukan adalah,

1.Peningkatan sarana dan prasarana pendukung SI/TI ditengah perkembangan TIK yang sangat cepat saat ini mendorong perusahaan melakukan pengadaan sarana dan prasarana yang diperlukan

2.Peningkatan infrastuktur dan aplikasi berbasis TIK, karena masih banyaknya sistem yang belum berbasis TIK guna mencapai hasil yang maksimal.

3. Peningkatan SI/TI yang handal.

4. Peningkatan kecepatan akses internet.

Mengacu pada strategi yang ada, maka dibuatlah perencanaan strategi jangka pendek 1 (satu) tahun, perencanaan stategi jangka menengah (kurang dari 5 tahun), dan perencaanaan strategi jangka panjang (lebih dari 5 tahun) yang diperoleh dari hasil analisis internal untuk pengembangan teknologi sistem informasi pada Bank sampah prabumulih.

Perencanaan Strategi Jangka Pendek ( 1 tahun )

Beberapa hal yang dimasukkan kedalam perencanaan strategi jangka pendek adalah pengembangan yang sifatnya merumuskan dasar dari pengembangan teknologi sistem informasi, yakni sebagai berikut :

a. Melakukan training dan workshop kepada karyawan untuk meningkatkan kompetensi teknologi informasi.

b. Melakukan peningkatan pelayanan berbasis internet.

c. Melakukan promosi melalui media web.

d. Mengalokasikan anggaran untuk peningkatan sarana dan prasarana teknologi informasi (TI).

Perencanaan strategi jangka panjang (5 tahun)

Beberapa hal yang dimasukkan kedalam perencanaan yang sifatnya melanjutkan perencanaan strategis jangka pendek dan memantapkan program pengembangan teknologi sistem informasi yang sudah berjalan, yakni sebagai berikut :

a. Menyiapkan infrastuktur sendiri untuk akses internet.

b. Memberikan kontribusi kepada masyarakat sekitar bank sampah dalam bentuk layanan resource IT.

c. Mengembangkan aplikasi baru pada kegiatan perusahaan.

d. Mengevaluasi kembali fungsi peralatan teknologi informasi disetiap unit kerja secara berkala.

e. Melakukan audit SI/TI

f. Meningkatkan jumlah sumber daya manusia yang handal dan memiliki kemampuan dibidang teknologi informasi disetiap unit kerja.

g. Menambah sarana dan prasarana teknologi informasi.

h. Menyediakan jaringan internet yang sesuai dengan tingkat kebutuhan organisasi bank sampah.

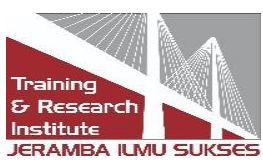




\subsection{Penggolongan Aplikasi}

Sistem Informasi dapat diterapkan secara internal dan eksternal perusahaan. Sistem Informasi Ekternal adalah sistem informasi yang ada di tarik keluar menjangkau ke pelanggan. Sistem informasi dapat diterapkan didalam fungsi-fungsi organisasi atau tingkatan-tingkatan organisasi , tergantung pada perusahaannya, jika struktur perusahaan pada fungsi-fungsi organisasinya maka unit-unit di perusahaan dikelompokkan kedalam beberapa ungsi atau depatemen seperti akuntasi, keuangan, pemasaran, produksi, sumber daya manusia dan sebagainya. Penggolongan aplikasi dilakukan untuk memudahkan pemetaan aplikasi berdasarkan fungsinya. Untuk melakukan Pemetaan aplikasi dapat menggunakan $M c$ Farlan Strategic Grid yang memetakan aplikasi ditinjau dari fungsinya terhadap proses bisnis.

Tabel 3. Penggolongan Aplikasi

No. Sistem Informasi

Kegunaan Unit

1. Sistem Informasi Perbankan BSP

aplikasi yang diwajibkan
untuk seluruh kegiatan operasional pada bank sampah Prabumulih. Aplikasi ini sangat membantu BSP karena

Membantu menyediakan layanan sampah keliling

Membantu menyediakan Staff Gudang layanan penjualan sampah
Customer

Service/Teller
2. SI Layanan sampah masyarakat keliling

3. SI Layanan penjualan sampah masyarakat

4. SI penjualan hasil daur ulang sampah
Membantu menyediakan Staff Gudang layanan produk hasil daur ulang berupa aneka keraiinan tanoan nunık

5. SI Pengelolaan Sumber Mengelola semua data yang Manajer Daya terkait dengan pengelolaan Humas/

6. SI Akuntansi dan Keuangan $\begin{array}{lrl}\text { Menyediakan } & \text { informasi } & \text { Manajer } \\ \text { mengenai perhitungan } & \text { Akuntansi dan } \\ \text { akuntansi dan ketuangan } & \text { Ketangan } \\ \text { secara menyeluruh, } & \\ \text { sehingga dapat membantu } & \end{array}$ 
7. Sistem Informasi Bank Mendukung kegiatan Manajer Bisnis Sampah berbasis Website operasional Bank sampah, dan

8. Sistem Informasi Bank Menyajikan data secara Manajer Bisnis Sampah berbasis Android transparan kepada Nasabah dan $\begin{array}{lrr}\text { Bank sampah } & \text { sekaligus } & \text { Manajemen } \\ \text { menyediakan } & \text { segala }\end{array}$ informasi terkait saldo. 


\subsection{Pemetaan Aplikasi Berdasarkan McFarlan Strategic Grid}

Hasil pemetaan Aplikasi McFarlan Strategic Grid:

Tabel 4. McFarlan Strategic Grid

STRATEGIS

\section{HIGH POTENTIAL}

Sistem Informasi Bank Sampah berbasis

Website

SI Perbankan BSP

Sistem Informasi Bank Sampah berbasis

Android

SI Layanan sampah masyarakat keliling

Gadget Komputer Internet

E-mail

SI Layanan penjualan sampah masyarakat

SI penjualan hasil daur ulang sampah

Sistem Informasi Pengelolaan

Sumber

Daya Manusia (SDM)

SI Akuntansi dan Keuangan

KEY OPERATIONAL

\section{SUPPORT}

\subsection{Prioritas Pengembangan Aplikasi}

Skala Prioritas Perencanaan Strategis SI/TI 1-5 Tahun Mencakup Strategi Bisnis SI dan Strategis Bisnis TI

Sistem informasi dan Teknologi Informasi merupakan solusi kebutuhan sistem informasi yang didapat berdasarkan kebutuhan sistem informasi yang dihasilkan dari analisa bisnis internal dan eksternal. Solusi kebutuhan sistem informasi yang diusulkan diharapkan dapat membantu bank sampah Prabumulih dalam menjalankan bisnisnya dan mampu memberikan keunggulan bersaing (competitive advantage).

Hal ini sesuai dengan pendapat Borwn (2005) yang menyatakan bahwa untuk mencapai

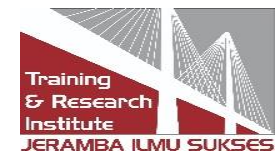


sebuah strategi yang telah ditetapkan oleh organisasi dalam rangka mempunyai keunggulan kompetitif, maka para pimpinan perusahaan, manajer operasi, haruslah bekerja dalam sebuah sistem yang ada pada proses perencanaan strategis / strategic planning (Brown, 2005).

Perencanaan Strategi SI/TI yang ada di Bank Sampah Prabumulih disesuaikan dengan visi, misi dan tujuan yang akan dicapai, serta tingkat kebutuhan SI/TI yang baik untuk peningkatan

pelayanan dan operasional bank sampah. Penentuan perencanaan strategis ini didapat dari hasil

analisis internal untuk pengembangan teknologi sistem informasi pada bank sampah Prabumulih.

Memfokuskan anggaran untuk membangun infrastruktur sistem informasi yang terintegrasi. Kebutuhan sistem informasi yang diperlukan antara lain sesuai dengan kebutuhan

yaitu, Perencanaan strategis SI mencakup aplikasi-aplikasi yang sangat dibutuhkan oleh bank sampah. Aplikasi strategis SI dihasilkan berdasarkan pemetaan pada McFarlan Strategic Grid

dapat dilihat pada tabel dibawah ini 
Tabel 5._Prioritas Pengembangan Aplikasi

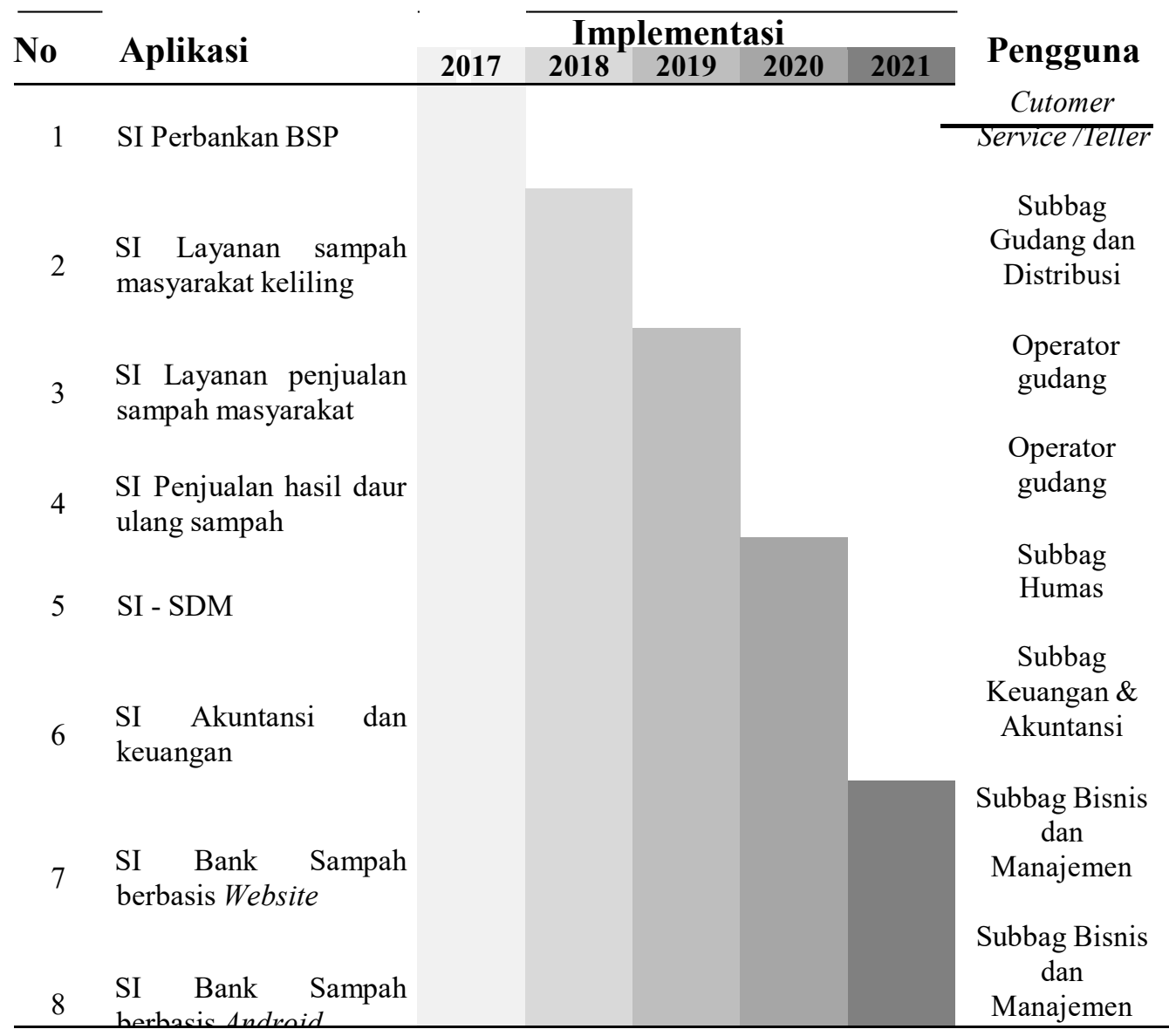

\section{Kesimpulan}

Dari hasil penelitian yang telah dirumuskan di atas, maka dapat disimpulkan bahwa :

1. Untuk merumuskan dokumen Restra SI/TI diperlukan suatu analisis kondisi saat ini dan analisis kebutuhan mendatang. Analisis kondisi saat ini dapat dilakukan dengan cara melakukan analisis terhadap proses bisnis (internal dan eksternal) dan analisis kondisi sistem informasi dan teknologi informasi (internal dan eksternal).

2. Analisis Portofolio aplikasi yang dihasilkan dari masing-masing analisis akan saling melengkapi sehingga diperoleh kebutuhan aplikasi secara menyeluruh, baik yang masih dibutuhkan untuk dikembangkan saat ini maupun aplikasi-aplikasi yang potensial untuk masa mendatang berdasarkan kebutuhan fungsional di Bank Sampah Prabumulih.

3. Hasil identifikasi dari perencanaan strategis sistem informasi dan teknologi informasi ini adalah terbentuknya portofolio aplikasi SI/TI yang menyajikan beberapa usulan aplikasi yang bernilai strategic, high potential, key operational dan support. Adapun rekomendasi prioritas usulan pengembangan aplikasi meliputi Sistem Informasi Bank Sampah berbasis Website, Sistem Informasi Sumber Daya Manusia, Sistem Informasi Bank Sampah berbasis Android, Sistem Informasi Layanan sampah keliling, penjualan sampah dan penjualan hasil daur ulang sampah yang nantinya akan menjadi landasan dalam pembuatan dokumen perencanaan strategis. 
Bank Sampah Prabumulih dapat menambahkan rencana anggaran dana khususnya untuk kebutuhan infrastruktur SI/TI agar dapat mewujudkan Renstra. Agar dapat memenuhi kebutuhan informasi yang diperlukan organisasi guna menunjang kegiatan operasional dengan memanfaatkan teknologi maka, dengan ini di rekomendasikan bahwa diperlukan adanya perubahan dan atau penambahan terhadap visi dan misi Bank Sampah Prabumulih yang berbasis TI dimasa yang akan datang.

\section{Referensi}

Akbar, M., \& Antoni, D. (2019). E-supply chain management value concept for the palm oil industry. Jurnal Sistem Informasi, 15(2), 15-29.

Antoni, D., Akbar, M., \& Fatoni, F. (2018). Electronic government Rukun Tetangga model. Jurnal Sistem Informasi, 14(2), 64-73.

Antoni, D., Fikari, D., Akbar, M., \& Jie, F. (2018). The readiness of palm oil industry in enterprise resource planning. Telkomnika, 16(6).

Antoni, D., Jie, F., \& Abareshi, A. (2020). Critical factors in information technology capability for enhancing firm's environmental performance: Case of Indonesian ICT sector. International Journal of Agile Systems and Management, 13(2), 15-181.

Ariana, S., Azim, C., \& Antoni, D. (2020). Clustering of ICT human resources capacity in the implementation of E-government in expansion area: A case study from Pali regency. Cogent Business \& Management, 7(1), 1754103.

Edition. John Wiley \& Sons.

Fauzi, F., Dencik, A. B., \& Asiati, D. I. (2019). Metodologi Penelitian Untuk Manajemen dan Akuntansi. Jakarta: Salemba Empat.

Rangkuti., \& Freddy. (1997). Analisis SWOT Teknik Membedah Kasus Bisnis: Berorientasi kosep Perencanaan Strategis Untuk Menghadapi Abad 21. Jakarta : PT. Gramedia Pustaka Utama.

Ward John dan Peppard. (2002). Strategic Planning for Information System. 3rd Ward John and Griffiths, P. (1996). Strategic Planning for Information System $2^{\text {nd }}$ ed. Chicester: John Wiley \& Sons.

\section{Copyrights}

Copyright for this article is retained by the author(s), with first publication rights granted to the journal.

This is an open-access article distributed under the terms and conditions of the Creative Commons Attribution license (http://creativecommons.org/licenses/by/4.0/) 